\title{
Survey of Vitamin A, $\beta$-Carotene, Calcium and Phosphorus Concentrations in Serum of Dairy Cows with Retained Placenta
}

\author{
Afshin Davasaztabrizi \\ Department of Clinical Sciences, Tabriz Branch, Islamic Azad University, Tabriz, Iran
}

\begin{abstract}
Retained Placenta (RP) may result from a number of factors, such as abortion, forced labor, delayed gestation, early parturition, uterine atony, infections and seasonal and hormonal disorders. In addition, it is well known that deficiencies of some vitamins and minerals induce or predispose animals to RP. The objective of the present study was to investigate the between serum concentrations vitamin A, $\beta$-carotene, calcium and phosphorus and the development of RP in cows. The 25 cows were retained placenta; to wit they have not excreted their placenta after parturition. The 20 others have excreted their placenta normally after parturition. Blood samples were obtained from all understudying animals from tail vein by venoject. Samples were centrifuged and sera were prepared and amounts of vitamin A, $\beta$-carotene, calcium and phosphorus were measured. Data showed that there is no significant difference among vitamin $\mathrm{A}$ and $\beta$-carotene between two groups ( $>0.05$ ). While revealed that there is a significant difference in mean value of $\mathrm{Ca}$ and $\mathrm{P}$ among two groups.
\end{abstract}

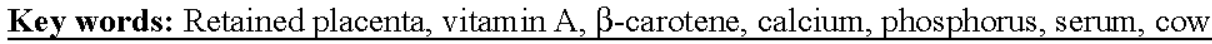

\section{INTRODUCTION}

Retained Placenta (RP) may result from a number of factors, such as abortion, forced labor, delayed gestation, early parturition, uterine atony, infectionsand seasonal and hormonal disorders. In addition, it is well known that deficiencies of some vitamins and minerals induce or predispose animals to RP (Hurley and Doane, 1989; Laven and Peters, 1996).

The physiological delivery of the placenta after parturition requires adequate and regular uterine contractions. The deficiency in secretions of PGF2a and oxytocin and serum $\mathrm{Ca}$ concentration which maintain adequate contraction of the uterus may cause RP, increase the risk of dystocia and delay the involution of the uterus (Hurley and Doane, 1989; McDowell, 1992; Morrow, 1980).

Some researchers (Shukla et al., 1983; Zhang et al., 1992) reported that a low serum Ca concentration plays an important role in the development of RP in cows while others (Lotthammer, 1983; Mutiga et al., 1993) found that the Ca concentration was at the physiological level, indicating that $\mathrm{Ca}$ has virtually no role in the development of RP.

Meanwhile, Carson et al. (1978) investigated the high incidence of dystocia, RP and puerperal metritis in a dairy herd. They found that when these animals were fed a ration enriched with supplemental bone meal for the previous 3 months the incidence of dystocia was reduced from $75-10 \%$, the RP rate from $35-8 \%$ and the puerperal metritis rate from $70-10 \%$. The serum Ca concentration in these cows was reported to increase from $8.98-10.26 \mathrm{mg}$ $\mathrm{dL}^{-1}$ with this type of diet.

It has been reported that the low serum concentrations of various minerals including $\mathrm{Zn}, \mathrm{Mg}$ and $\mathrm{K}$ in cows before parturition might cause or increase the risk of RP (Stancioiu and Constantinescu, 1983; Zhang et al., 1992).

Malnutrition is thought to be one of the most important factors in non-infectious abortion in cows and heifers. It may even lead to the development of abnormalities in the fetus and embryonic death in the early period of gestation. The inadequate supplementation of a ration with vitamins $\mathrm{A}$ and $\mathrm{E}$, betacarotene, iodine, $\mathrm{Se}, \mathrm{Cu}$ and $\mathrm{Zn}$ may also induce abortion in the advanced stage of gestation in cows (Allison and Laven, 2000; Graham et al., 1994).

The transition period for dairy cows is characterized by increased risk of several metabolic and infectious diseases. One important causal factor is impaired immune function in peripartum cows (Mallard et al., 1998) and cows' vitamin $\mathrm{A}$ and vitamin $\mathrm{E}$ status are component factors in immune function (NRC, 2001).

Peripartum immunosuppression is multifactorial but is associated with endocrine changes and decreased intake of critical nutrients (Goff and Horst, 1997). Circulating concentrations of vitamins $\mathrm{A}$ and $\mathrm{E}$ decrease around calving (Goff et al., 2002). Decreased 
phagocytosis and intracellular killing by neutrophils occur in parallel with decreased DMI and decreased circulating vitamin $\mathrm{E}$ ( $\alpha$-tocopherol) concentration (Hogan et al., 1992). Vitamin $E$ is a fat-soluble membrane antioxidant that enhances the functional efficiency of neutrophils by protecting them from oxidative damage following intracellular killing of ingested bacteria (Herdt and Stowe, 1991). Several studies (Weiss et al., 1990, 1992) have shown that dietary supplementation with $1000 \mathrm{IU}$ of vitamin $\mathrm{E} / \mathrm{cow} /$ day in the late dry period mitigates the peripartum drop in circulating $\alpha$-tocopherol but this does not necessarily decrease the incidence of disease (Allison and Laven, 2000). $\beta$-carotene is the main dietary precursor of vitamin A (retinol) in dairy cattle. $\beta$-carotene that escapes rumen degradation is metabolized in the intestinal mucosa to retinol and absorbed and transported to the liver with fat (Chew, 1987). Vitamin A has numerous functions that are not fully understood. In peripartum dairy cows, it is reported to have a role in resistance to infectious disease, particularly mastitis (NRC, 2001). In dairy cattle, $\beta$-carotene may also exert an effect as an antioxidant, separate from its role as provitamin A (Chew, 1993).

The objective of the present study was to investigate the relationship between blood serum concentrations of vitamin $\mathrm{A}, \beta$-carotene, Calcium and Phosphorus and the development of RP in cows.

\section{MATERIALS AND METHODS}

Researchers used of 45 cows for this study which are divided into two groups as follow: The 25 of them were retained placenta; to wit they have not excreted their placenta after parturition. The 20 others have excreted their placenta normally after parturition. Blood samples were obtained from all understudying animals from tail vein by venoject. Samples were centrifuged and sera were prepared. Vitamin $\mathrm{A}$ and $\beta$-carotene measured by $\mathrm{N}$-hexane Method and $\mathrm{Ca}$ and $\mathrm{P}$ of sera were measured by Calorimetric Method and by using of Zeist-Chemistry Co. kits. Data were recorded and analyzed by SPSS software.

\section{RESULTS AND DISCUSSION}

Data showed that there is no significant difference among vitamin $\mathrm{A}$ and $\beta$-carotene between two groups $(p>0.05)$. While revealed that there is a significant difference in mean value of $\mathrm{Ca}$ and $\mathrm{P}$ among two groups (Table 1 and Fig. 1-4).

In a research (Shukla et al., 1983; Zhang et al., 1992) carried out on blood samples taken from cows prior to parturition, $24 \mathrm{~h}$ after parturition and postpartum 1st week, it is suggested that the serum $\mathrm{Ca}$ concentration of $\mathrm{RP}$
Table 1: Mean value of vitamin A, caLcium, $\beta$-carotene and phosphorus in two groups

\begin{tabular}{lccccc}
\hline Parameters & Unit & Groups & No. of samples & Mean $\pm \mathrm{SD}$ & $\mathrm{p}$-values \\
\hline Vitamin A & $\mathrm{mg} \mathrm{dL}^{-1}$ & $1^{*}$ & 25 & $24.65 \pm 4.08$ & $>0.05$ \\
& & $2^{* * *}$ & 20 & $25.34 \pm 6.21$ & \\
$\beta$-carotene & $\mathrm{mg} \mathrm{dL}^{-1}$ & 1 & 25 & $13.72 \pm 2.83$ & $>0.05$ \\
& & 2 & 20 & $14.13 \pm 3.12$ & \\
$\mathrm{Ca}$ & $\mathrm{mg} \mathrm{dL}^{-1}$ & 1 & 25 & $8.21 \pm 0.03$ & $<0.05$ \\
& & 2 & 20 & $9.35 \pm 0.07$ & \\
$\mathrm{P}$ & $\mathrm{mg} \mathrm{dL}^{-1}$ & 1 & 25 & $4.80 \pm 0.02$ & $<0.05$ \\
& & 2 & 20 & $6.47 \pm 0.04$ & \\
\hline
\end{tabular}

*Retained placenta; **Without retained placenta

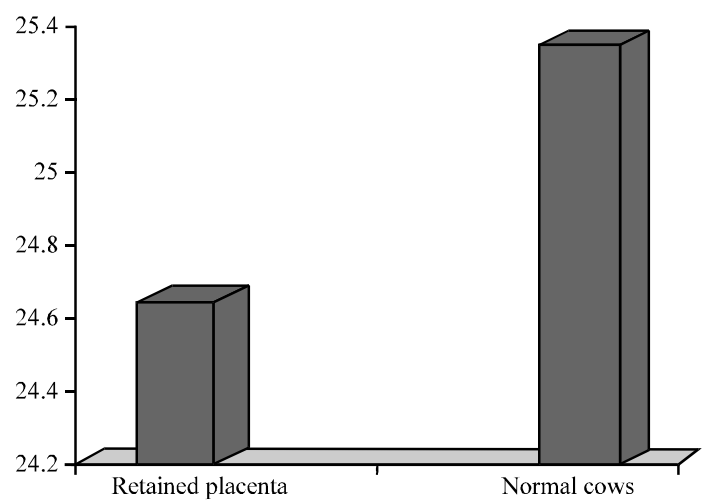

Fig. 1: Comparison of mean value of vitamin $\mathrm{A}$ in two groups

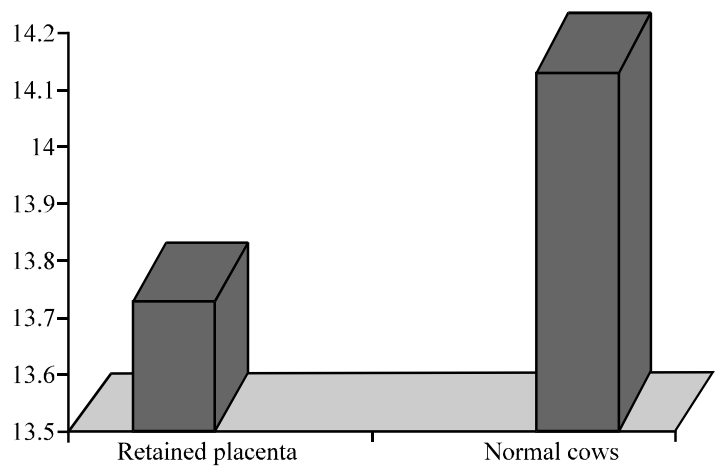

Fig. 2: Comparison of mean value of $\beta$-carotene in two groups

animals $\left(6.27 \pm 0.18 \mathrm{mg} \mathrm{dL}^{-1}\right)$ was lower than that in postpartum cows without $\mathrm{RP}\left(7.40 \pm 0.18 \mathrm{mg} \mathrm{dL}^{-1}\right)$. Some researchers (Lotthammer, 1983; Mutiga et al., 1993) indicate that a significant difference is not seen between animals with and without RP. Lotthammer (1983) stated that $\mathrm{Ca}$ affected the development of $\mathrm{RP}$ and the serum $\mathrm{Ca}$ concentration was $6.89,6.65$ and $6.37 \mathrm{mg} \mathrm{dL}^{-1} 1$ week before during and $12 \mathrm{~h}$ after parturition, respectively in cows with RP. On the other hand, these values were reported as $9.09,8.61$ and $8.53 \mathrm{mg} \mathrm{dL}^{-1}$, respectively in cows without RP. The average serum Ca concentrations in cows with RP were lower than the values of those without RP in the research. This finding is in agreement 


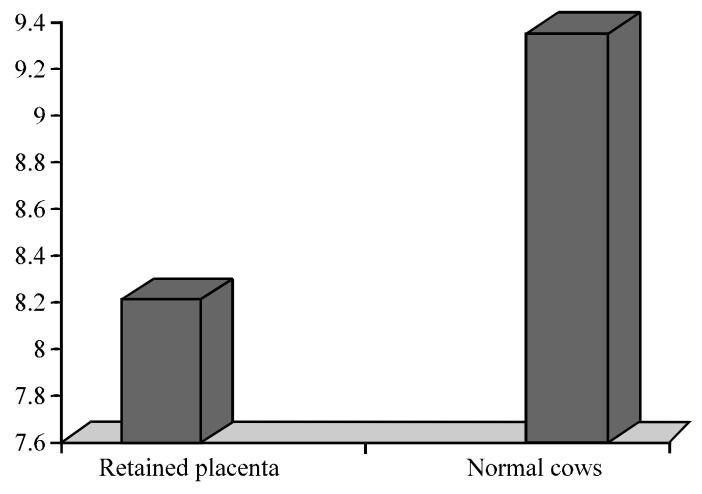

Fig. 3: Comparison of mean value of $\mathrm{Ca}$ in two

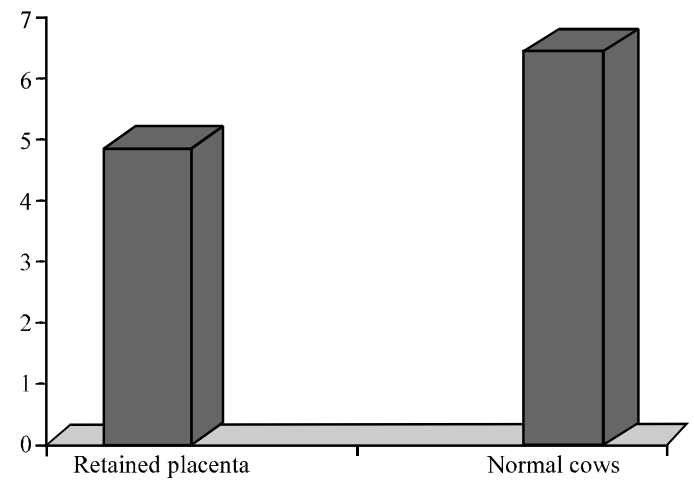

Fig. 4: Comparison of mean value of $\mathrm{P}$ in two

with the results of some other researchers (Bari et al., 1996; Shukla et al., 1983; Zhang et al., 1992). Bari et al. (1996) stated that $\mathrm{Mg}$ concentration was 1.75 and $2.84 \mathrm{mg}$ $\mathrm{dL}^{-1}$ and the differences were significant. Zhang et al. (1992) suggested that $\mathrm{Zn}$ and $\mathrm{Mg}$ concentrations of the blood serum in the RP group prior to parturition and after parturition were lower than those in the control animals. Other researchers (Darmono and Sudibyo, 1990; Graham et al., 1995; Sevcik et al., 1980) indicated that low levels of minerals lead to a predisposition to RP in cows. It was suggested in many studies (Correa et al., 1990; Laven and Peters, 1996; Samad and Islam, 1989) that dystocia in cows increased RP incidence. Sevcik et al. (1980) stated that the blood serum $\mathrm{Ca}, \mathrm{Na}$ and $\mathrm{K}$ concentrations did not differ between normal cows and those with dystocia. On the other hand, Bostedt (1974) indicated that the serum $\mathrm{Ca}$ and $\mathrm{Mg}$ concentrations in cows and heifers after dystocia were higher than those in cows with normal parturition. In this research, no differences were seen in respect of $\mathrm{Ca}, \mathrm{Zn}, \mathrm{Mg}, \mathrm{K}$ or Na levels between the RP and control groups depending on the parturition type. These results are consistent with previous research (Sevcik et al., 1980).

Mutiga et al. (1993) indicated that calf sex in RP cows had no effect on plasma Ca levels. Ocal stated that the serum Ca level in cows having a male calf with RP was higher than that in cows having a female calf (9.39 and $\left.8.68 \mathrm{mg} \mathrm{dL}^{-1}\right)$. In the present research, no difference was determined among $\mathrm{Ca}, \mathrm{Zn}, \mathrm{Mg}, \mathrm{K}$ or Na levels depending on calf sex in the RP and control groups. Some researchers (Laven and Peters, 1996; Stevenson and Call, 1983) suggest that there is a relation between the age of the animal and RP thus RP incidence increases with age. In research conducted by Erb and Martin (1980) on 1401 cows, it was stated that the RP rate in 2 years old cows was lower than that in cows 4 years old. Ocal reported that cows 2-3 years old with RP had higher serum $\mathrm{Ca}\left(9.41\right.$ and $\left.8.72 \mathrm{mg} \mathrm{dL}^{-1}\right)$ levels than cows 3-6 years old.

\section{CONCLUSION}

With respect to determinants of peripartum serum concentrations of $\alpha$-tocopherol, $\beta$-caroteneand retinol, major factors such as DMI and the level of dietary supplementation were not measured in this study. Dry matter intake and diet composition similarly have significant influence on metabolites such as NEFA and cholesterol. However in alarge, multi-herd field study with the cow as the unit of interest, it was not feasible to collect detailed information on diets.

\section{REFERENCES}

Allison, R.D. and R.A. Laven, 2000. Effect of vitamin E supplementation on the health and fertility of dairy cows: A review. Vet. Rec., 147: 703-708.

Bari, M.Z., M.A. Saeed, I.N. Bashir and H.M. Shoaib, 1996. Comparative study on serum levels of Calcium, Inorganic Phosphorus and Magnesium in cows with and without retention of placenta. Indian J. Anim. Nutr., 13: 63-66.

Bostedt, H., 1974. Studies on the calcium, inorganic phosphate and magnesium content of the blood serum of cattle in relation to difficulties at parturition. Zentralbl. Veterinarmed., 20: 172-178.

Carson, R.L., A.B. Caudle and H.E. Riddle, 1978. The relationship between narrow calcium-phosphorus ratio and reproductive problems in a dairy herd: $\mathrm{A}$ case report. Theriogenology, 9: 505-507.

Chew, B.P., 1987. Vitamin A and $\beta$-carotene in host defense. J. Dairy Sci., 70: 2732-2743.

Chew, B.P., 1993. Role of carotenoids in the immune response. J. Dairy Sci., 76: 2804-2811.

Correa, M.T., C.R. Curtis, H.E. Erb, J.M. Scarlett and R.D. Smith, 1990. An ecological analysis of risk factors for postpartum disorders of Holstein Friesian cows for thirty two New York farms. J. Dairy Sci., 73: 1515-1524. 
Darmono, A. and A. Sudibyo, 1990. Concentrations of calcium, magnesium and copper in serum samples of cattle known to be positive for brucellosis in Indonesia. Penyakit Hewan, 22: 59-61.

Erb, H.N. and S.W. Martin, 1980. Interrelationships between production and reproductive diseases in holstein cows: Age and seasonal patterns. J. Dairy Sci., 63: 1918-1924.

Goff, J.P. and R.L. Horst, 1997. Physiological changes at parturition and their relationship to metabolic disorders. J. Dairy Sci., 80: 1260-1268.

Goff, J.P., K. Kimura and R.L. Horst, 2002. Effect of mastectomy on milk fever, energy and vitamins $\mathrm{A}, \mathrm{E}$ and $\beta$-carotene status at parturition. J. Dairy Sci., 85: $1427-1436$.

Graham, T.W., M.C. Thurmond, M.E. Gershwin, J.P. Picanso, J.S. Garvey and C.L. Keen, 1994. Serum zinc and copper concentrations in relation to spontaneous abortion in cows: implications for human fetal loss. J. Reprod. Fertil., 105: 253-262.

Graham, T.W., S.N. Giri, P.F. Daels, J.S. Cullor and C.L. Keen et al., 1995. Associations among prostaglandin F2 alpha, plasma zinc, copper and iron concentrations and fetal loss in cows and mares. Theriogenology, 44: 379-390.

Herdt, T.H. and H.D. Stowe, 1991. Fat-soluble vitamin nutrition for dairy cattle. Vet. Clin. North Am. Food Anim. Practice, 7: 391-415.

Hogan, J.S., W.P. Weiss, D.A. Todhunter, K.L. Smith and P.S. Schoenberger, 1992. Bovine neutrophil responses to parenteral vitamin E. J. Dairy Sci., 75: 399-405.

Hurley, W.L. and R.M. Doane, 1989. Recent developments in the roles of vitamins and minerals in reproduction. J. Dairy. Sci., 72: 784-804.

Laven, R.A. and A.R. Peters, 1996. Bovine retained placenta: Aetiology, pathogenesis and economic loss. Vet. Rec., 139: 465-471.

Lotthammer, K.H., 1983. Comparative studies of the course of mineral, metabolite, enzyme and hormone levels in blood serum ante partum in dairy cows with and without later retained placenta. Dtsch. Tierarztl. Wochenschr., 90: 427-433.

Mallard, B.A., J.C. Dekkers, M.J. Ireland, K.E. Leslie and S. Sharif et al., 1998. Alteration in immune responsiveness during the peripartum period and its ramification on dairy cow and calf health. J. Dairy Sci., 81: 585-595.
McDowell, L.R., 1992. Minerals in Animal and Human Nutrition. Academic Press, San Diego, CA., USA.

Morrow, D.A., 1980. The Role of Nutrition in Dairy Cattle Reproduction. In: Current Therapy in Theriogenology, Morrow, D.A. (Ed.)., W.B. Saunders Co., Philadelphia, pp: 449-455.

Mutiga, E.R., K. Mbai, V.T. Tsuma, P.T. Karitu and S.O. Ojiayo, 1993. Incidence and causes of retained placenta in smallholder dairy herds. Indian Vet. J., 70: 333-336

NRC, 2001. Nutrient Requirements of Dairy Cattle. 7th Edn., National Academic Press, Washington, DC., ISBN: 9780309069977, Pages: 381.

Samad, R.M.H. and T.S. Islam, 1989. Factors associated with placental retention in dairy cattle. Indian J. Dairy Sci., 42: 720-723.

Sevcik, A., J. Elecko and J. Kacmarik, 1980. Effect of parturition on some components of mineral metabolism in cows. Folia Vet, 24: 89-101.

Shukla, S.P., K.G. Kharche and H.K.B. Parekh, 1983. Calcium and phosphorus in relation to retained placenta in cross-bred cows. Indian Vet. J., 60: $183-188$.

Stancioiu, N. and D. Constantinescu, 1983. Variation in the concentration of some blood minerals in cows with normal calving and with retained placenta. Med. Vet., 26: 29-31.

Stevenson, J.S. and E.P. Call, 1983. Reproductive disorders in the periparturient dairy cow. J. Dairy Sci., 71: 2572-2583.

Weiss, W.P., D.A. Todhunter, J.S. Hogan and K.L. Smith, 1990. Effect of duration of supplementation of selenium and vitamin $\mathrm{E}$ on periparturient dairy cows. J. Dairy Sci., 73: 3187-3194.

Weiss, W.P., J.S. Hogan, K.L. Smith, D.A. Todhunter and S.N. Williams, 1992. Effect of supplementing periparturient cows with vitamin $\mathrm{E}$ on distribution of $\alpha$-tocopherol and calcium salts of fatty acids on vitamin $\mathrm{E}$ and fatty acid composition of cows milk. J. Dairy Sci., 73: 2832-2832.

Zhang, C.K., J.P. Ye and J.H. Chen, 1992. The changes of mineral contents of serum during the dry period and prior to and after calving in dairy cows with retained placenta. Chin. J. Vet. Med., 18: 10-11. 